\title{
Nutrients and foods consumed by New Zealand children on schooldays and non-schooldays
}

\author{
Jennifer E Rockell*, Winsome R Parnell, Noela C Wilson, Paula ML Skidmore and \\ Asher Regan \\ Department of Human Nutrition, University of Otago, PO Box 56, Dunedin 9054, New Zealand
}

Submitted 16 September 2009: Accepted 1 June 2010: First published online 13 July 2010

\begin{abstract}
Objective: To describe and compare food and nutrient intakes in New Zealand (NZ) children on schooldays and non-schooldays.

Design: Secondary analysis of cross-sectional data from the NZ 2002 Children's Nutrition Survey. Dietary intake was assessed using computer-assisted multi-pass $24 \mathrm{~h}$ dietary recalls in the home. Data were adjusted for survey weightings to be representative of the $\mathrm{NZ}$ population. The effect of day category on nutrient intake, and likelihood of consumption of food categories were determined using linear and logistic regression.

Setting: NZ homes and schools.

Subjects: A total of 2572 children (538 non-schooldays and 2034 schooldays) at the age of 5-14 years.

Results: There were differences in the proportion consuming some food groups between schooldays and non-schooldays, although the majority of nutrient intakes including energy did not differ by day category. Mean cholesterol intake was higher on non-schooldays; dietary fibre and available carbohydrate, in particular sucrose and fructose, were higher on schooldays. Hot chips were twice as likely to be consumed on a non-schoolday. Soft drink consumption was higher on non-schooldays for Māori/New Zealand European and others and powdered drinks/cordial consumption did not vary by day category. More children consumed snack bars (normal weight, obese), fruit, sandwiches, biscuits/crackers and snack foods on schooldays. There was no difference in consumption of pies/ sausage rolls by day category.

Conclusions: The proportion of consumers of a variety of foods differed significantly between non-schooldays and schooldays; few nutrient intakes differed. The present study indicates that family food, wherever it is consumed, is the mainstay of nutrition for NZ schoolchildren.
\end{abstract}



Efforts to improve the diets of children have largely focused on the school environment ${ }^{(1,2)}$. Reports of foods popularly sold in schools have bolstered concerns about the impact of the school environment on children's nutrition overall ${ }^{(3)}$. School environments may be influenced by government policy with regard to both what may be sold on the premises and curriculum content. However, children only attend school on about one-half of the days of the year (190-200 d for New Zealand (NZ) children $)^{(4)}$. In addition, only approximately one-third of children's nutrient and energy intakes are consumed during school hours ${ }^{(5)}$. Meals are not provided by NZ schools, although food items are usually available for purchase at tuck shops/canteens, a situation similar to Australia and Denmark. This means that it is particularly important to consider the role of the non-school environment, lunches sourced from home, on overall intake.
The times and patterns of children's eating on schooldays and non-schooldays (day category) differ, and therefore it might be expected that nutrient intakes also differ between day categories. However, there are very few published data describing and comparing intakes by day category, and where data are available they are from countries in which school meals are provided ${ }^{(6-8)}$. Texan children (9-12 years) consumed less energy and a slightly higher energy from fat on weekends ${ }^{(6)}$. US children (6-11 years; 1994-1996 Continuing Survey of Food Intakes by Individuals) had no difference for energy intake, energy from fat or carbohydrate, but a lower intake of protein as a percentage of energy (\%E), on Fridays and weekends ${ }^{(7)}$. A small survey of Scottish children (5-17 years) found no difference in the intake of energy, fat, saturated fat $(\% \mathrm{E})$ or non-milk extrinsic sugars between term time $v$. holidays, or weekends $v$. weekdays ${ }^{(8)}$. However, data 
about foods consumed and intake of other nutrients have not been addressed in any of these studies.

Although nutrient intakes of NZ children are reported as satisfactory for most nutrients ${ }^{(9)}$ (nutrients of concern include calcium, iron and vitamin $\mathrm{A}^{(9)}$ ), there is a need to explore whether day category has any association with intake of these nutrients. There is a high prevalence of overweight (21\%) and obesity (10\%) in NZ children ${ }^{(9)}$ and dietary efforts to address this issue have focused on making 'healthy' food choices in the school environment ${ }^{(10)}$ but have not addressed the equally important non-school environment.

The present study of a nationally representative sample of children compares nutrient and food intake on schooldays $v$. non-schooldays, with ethnic comparisons.

\section{Methods}

The present study is a secondary analysis of the NZ 2002 Children's Nutrition Survey, a cross-sectional survey of a national sample of children (5-14 years), during the 2002 school year.

A school-based sampling frame was used, with an oversampling of Māori and Pacific children to allow for ethnic-specific analyses. Of the 190 schools sampled, 172 (91\%) participated in the study. Recruitment from each school was in proportion to the number of students on the school roll. Children were assigned to one of three ethnic categories: Māori, Pacific or New Zealand European and others (NZEO), with a different probability of selection by ethnicity, based on their distribution from the 2001 school rolls. Of the 4728 children invited to participate, 3275 (69\%) participated in the study.

Socio-economic status was assigned using the New Zealand Index of Deprivation (NZDep01), derived from the child's residential address, and based on eight dimensions, including income, access to a car and living space $^{(11)}$. Details of the survey methodology are described elsewhere ${ }^{(9)}$. All thirteen NZ regional health ethics committees gave approval for the survey.

Trained interviewers collected dietary intake data using a computer-assisted three-pass $24 \mathrm{~h}$ dietary recall in children's homes. Children recalled all food/drinks consumed in the $24 \mathrm{~h}$ before the interview. Nutrient intakes were calculated (NZ Food Composition database ${ }^{(12)}$ ). Foods consumed were coded to food groups for calculation of prevalence of consumption (Appendix).

Non-schooldays included weekends, national public holidays and school holidays ${ }^{(4)}$. Children recalled intake during the $24 \mathrm{~h}$ before the interview; thus, recalls that included both schooldays and non-schooldays ( $n$ 703) were not included in these analyses. The remaining recalls were categorized by day category, as schooldays only or non-schooldays only.

Height and weight were taken at each child's school using portable standardized equipment. BMI was calculated and the reference cut-off values of Cole $e t a l .{ }^{(13)}$ were used to categorize children as normal, overweight or obese. BMI category was available for 2393 (93\%) children with recalls included in the present analysis.

Statistical analyses were carried out using the STATA statistical software package version 10.01SE (StataCorp, College Station, TX, USA). Survey commands used sampling weights and primary sampling units (schools) ensuring that the results were representative of the NZ population. Variables whose distributions were not normal were transformed to logarithms. Multiple linear regression was used to examine the relationship between day category and nutrient intake. Because age, sex, ethnicity, NZDep01 and obesity have been associated with food choices and/or nutrient intake, these variables were included in the model. Age was considered a categorical variable (5-6, 7-10 and 11-14 years) and NZDep01 status as quintiles. We estimated the adjusted mean nutrient intake for day categories based on these models. Logistic regression was used for estimating the prevalence (95\% CI) of consumers of food groups by day category, and interactions between day category, sex, age, ethnicity and BMI category were tested using the standard statistical techniques embedded in STATA. A $P$ value of $<0.05$ was considered statistically significant.

\section{Results}

There were 2034 children whose $24 \mathrm{~h}$ dietary recall period covered schooldays; 538 children recalled non-schooldays (Table 1).

\section{Nutrient intake}

Energy and micronutrient intake did not differ by day category. However, cholesterol intake on non-schooldays

Table 1 Characteristics of children

\begin{tabular}{|c|c|c|c|c|}
\hline & \multicolumn{2}{|c|}{ Schooldays } & \multicolumn{2}{|c|}{ Non-schooldays* } \\
\hline & $n$ & $\%$ & $n$ & $\%$ \\
\hline All participants ( $n$ 2572) & \multicolumn{2}{|c|}{$(n 2034)$} & \multicolumn{2}{|c|}{$(n 538)$} \\
\hline Sex & & & & \\
\hline Male & 1079 & 53 & 252 & 47 \\
\hline Female & 955 & 47 & 286 & 53 \\
\hline \multicolumn{5}{|l|}{ Age groups (years) } \\
\hline $5-6$ & 427 & 21 & 114 & 21 \\
\hline $7-10$ & 875 & 43 & 227 & 42 \\
\hline $11-14$ & 732 & 36 & 197 & 37 \\
\hline \multicolumn{5}{|l|}{ Ethnicity } \\
\hline NZEO & 641 & 32 & 153 & 28 \\
\hline Māori & 794 & 39 & 174 & 32 \\
\hline Pacific & 599 & 29 & 211 & 39 \\
\hline \multicolumn{5}{|l|}{ BMI category $\left(\mathrm{kg} / \mathrm{m}^{2}\right) \dagger$} \\
\hline Normal & 1148 & 61 & 311 & 62 \\
\hline Overweight & 468 & 25 & 120 & 24 \\
\hline Obese & 272 & 14 & 74 & 15 \\
\hline
\end{tabular}

NZEO, New Zealand European and others.

*Non-schooldays are weekends, national and school holidays. tBMI category was not available for 179 children. 
Table 2 Mean daily nutrient intake, by schooldays and non-schooldays

\begin{tabular}{|c|c|c|c|c|c|c|c|}
\hline \multirow[b]{2}{*}{ Nutrient } & \multicolumn{2}{|c|}{ Schooldays } & \multicolumn{2}{|c|}{ Non-schooldays } & \multirow[b]{2}{*}{ Coefficient } & \multirow[b]{2}{*}{$95 \% \mathrm{Cl}$} & \multirow[b]{2}{*}{$P$ value* } \\
\hline & Mean & $95 \% \mathrm{Cl}$ & Mean & $95 \% \mathrm{Cl}$ & & & \\
\hline Energy (kJ) & 8298 & 8121,8478 & 7915 & 7504,8349 & 1.05 & $0 \cdot 99,1 \cdot 11$ & $0 \cdot 131$ \\
\hline \multicolumn{8}{|l|}{ Protein $(g)^{a}$} \\
\hline Normal weight & 64 & 61,66 & 63 & 60,68 & $1 \cdot 00$ & $0.93,1.08$ & 0.975 \\
\hline Overweight & 62 & 58,66 & 69 & 62,77 & 0.90 & $0.78,1.03$ & $0 \cdot 111$ \\
\hline Obese & 71 & 66,77 & 61 & 54,68 & $1 \cdot 17$ & $1 \cdot 02,1 \cdot 34$ & 0.026 \\
\hline Total fat $(\mathrm{g})$ & 72 & 70,74 & 70 & 66,75 & 1.02 & $0 \cdot 95,1 \cdot 10$ & 0.557 \\
\hline Total SFA (g) & 30 & 29,31 & 30 & 28,32 & $1 \cdot 02$ & $0 \cdot 94,1 \cdot 11$ & 0.694 \\
\hline Cholesterol (mg) & 170 & 162,177 & 189 & 173,207 & 0.90 & $0.80,1 \cdot 00$ & 0.049 \\
\hline Available carbohydrate $(\mathrm{g})$ & 262 & 256,269 & 241 & 228,254 & 1.09 & $1 \cdot 02,1 \cdot 16$ & 0.008 \\
\hline Starch (g) & 143 & 139,147 & 129 & 122,136 & $1 \cdot 11$ & $1 \cdot 04,1 \cdot 18$ & 0.001 \\
\hline Sucrose $(\mathrm{g})$ & 54 & 52,57 & 48 & 42,54 & $1 \cdot 14$ & $1 \cdot 01,1 \cdot 30$ & 0.041 \\
\hline \multicolumn{8}{|l|}{ Fructose $(\mathrm{g})^{\mathrm{b}}$} \\
\hline NZEO & $13 \cdot 2$ & $11 \cdot 8,14 \cdot 9$ & $14 \cdot 1$ & $12 \cdot 3,16 \cdot 1$ & 0.94 & $0 \cdot 80,1 \cdot 10$ & 0.456 \\
\hline Māori & $15 \cdot 1$ & $13 \cdot 9,16 \cdot 5$ & $14 \cdot 5$ & $12 \cdot 4,17 \cdot 0$ & 1.04 & $0 \cdot 88,1 \cdot 24$ & $0 \cdot 620$ \\
\hline Pacific & $15 \cdot 5$ & $14 \cdot 2,17 \cdot 0$ & $10 \cdot 8$ & $9 \cdot 0,12 \cdot 8$ & $1 \cdot 44$ & $1 \cdot 19,1 \cdot 74$ & 0.000 \\
\hline Maltose (g) & $2 \cdot 8$ & $2 \cdot 7,3 \cdot 0$ & $2 \cdot 2$ & $1 \cdot 9,2 \cdot 5$ & $1 \cdot 28$ & $1 \cdot 10,1 \cdot 48$ & 0.001 \\
\hline \multicolumn{8}{|l|}{ Glucose $(\mathrm{g})^{\mathrm{b}}$} \\
\hline NZEO & $12 \cdot 6$ & $11 \cdot 3,14 \cdot 0$ & $13 \cdot 7$ & $12 \cdot 0,15 \cdot 7$ & 0.92 & $0.79,1.07$ & 0.256 \\
\hline Maori & $14 \cdot 1$ & $12 \cdot 8,15 \cdot 4$ & $14 \cdot 1$ & $12 \cdot 1,16 \cdot 6$ & 0.99 & $0 \cdot 83,1 \cdot 18$ & 0.941 \\
\hline Pacific & $13 \cdot 7$ & $12 \cdot 4,15 \cdot 1$ & $9 \cdot 8$ & $8 \cdot 2,11 \cdot 7$ & $1 \cdot 40$ & $1 \cdot 19,1 \cdot 66$ & 0.000 \\
\hline Lactose $(\mathrm{g})$ & $7 \cdot 0$ & $6 \cdot 2,8 \cdot 0$ & $5 \cdot 6$ & $4 \cdot 5,7 \cdot 0$ & $1 \cdot 25$ & $0.99,1.58$ & 0.056 \\
\hline Dietary fibre (g) & 17 & 16,17 & 15 & 14,16 & $1 \cdot 11$ & $1 \cdot 02,1 \cdot 21$ & 0.013 \\
\hline Calcium (mg) & 583 & 556,612 & 548 & 508,591 & 1.06 & $0.98,1 \cdot 15$ & $0 \cdot 131$ \\
\hline Iron (mg) & 10 & 10,10 & 10 & 9,10 & 1.05 & $0 \cdot 98,1 \cdot 12$ & $0 \cdot 148$ \\
\hline Zinc (mg) & $8 \cdot 8$ & $8 \cdot 5,9 \cdot 1$ & 8.9 & $8 \cdot 3,9 \cdot 5$ & 0.99 & $0.92,1.07$ & 0.822 \\
\hline \multicolumn{8}{|l|}{ Vitamin C $(\mathrm{mg})^{\mathrm{a}}$} \\
\hline Normal weight & 68 & 62,75 & 55 & 46,65 & $1 \cdot 24$ & $1 \cdot 01,1 \cdot 52$ & $0 \cdot 040$ \\
\hline Overweight & 61 & 54,70 & 67 & 54,85 & 0.91 & $0 \cdot 70,1 \cdot 19$ & 0.489 \\
\hline Obese & 78 & 66,91 & 54 & 43,68 & $1 \cdot 45$ & $1 \cdot 06,1 \cdot 98$ & $0 \cdot 020$ \\
\hline Vitamin A $(\mu \mathrm{g})$ & 454 & 431,479 & 443 & 407,483 & 1.02 & $0.93,1.13$ & 0.621 \\
\hline Retinol $(\mu \mathrm{g})$ & 252 & 239,265 & 243 & 221,266 & 1.04 & $0.93,1.15$ & 0.489 \\
\hline$\beta$-Carotene equivalents $(\mu \mathrm{g})$ & 771 & 716,830 & 738 & 638,853 & 1.04 & $0.88,1 \cdot 23$ & 0.607 \\
\hline Riboflavin (mg) & $1 \cdot 4$ & $1 \cdot 3,1 \cdot 5$ & $1 \cdot 3$ & $1 \cdot 2,1 \cdot 4$ & 1.08 & $0.98,1 \cdot 20$ & $0 \cdot 101$ \\
\hline
\end{tabular}

Significant interaction between the effect of day category and BMI category ${ }^{\mathrm{a}}$ and ethnicity ${ }^{\mathrm{b}}$.

Nutrient intake is log transformed for skewness; data are presented as geometric means.

*Linear regression controlled for ethnicity, age, sex, New Zealand Index of Deprivation (NZDep01), BMI category, adjusted for survey weighting

was slightly higher than on schooldays. The available carbohydrate, starch, sucrose and dietary fibre intakes were higher on schooldays than on non-schooldays (Table 2).

There was an interaction between BMI category and the effect of day category on vitamin $\mathrm{C}$ intake and on protein intake. Mean protein intake was higher on schooldays for obese children, but did not differ significantly by day category for normal/overweight. Obese children had higher vitamin $\mathrm{C}$ intake on non-schooldays, but intake by normal/overweight did not differ by day category. There was an interaction between ethnicity and day category on fructose and glucose intake; intakes were lower on non-schooldays for Pacific children, but did not differ significantly by day category for NZEO/Māori children.

\section{Food groups}

Table 3 lists all food groups in which at least 10\% of children consumed an item from the food group by day category, and presents the proportion of consumers of selected food groups. On schooldays, children were more likely to consume sandwiches, biscuits/crackers and fruit than on non-schooldays.
There was a difference in the effect of day category on snack foods consumption, by ethnicity; while all ethnicities had a greater likelihood of consuming snack foods on a schoolday than a non-schoolday, the effect was more pronounced for Māori children.

There was a difference by day category in the consumption of snack bars by BMI category. Prevalence of intake did not differ by day category for overweight children, but snack bar consumption was higher on schooldays for normal and obese children.

On non-schooldays, more children consumed confectionery compared with schooldays. Hot chips consumption did not differ by day category for Pacific children, but more NZEO/Māori children consumed hot chips on non-schooldays than on schooldays.

There was a difference by day category on soft drink consumption, by ethnicity. There was no difference for Pacific children; NZEO/Māori children were less likely to have soft drinks on schooldays.

There was no difference in the odds of consuming pies/sausage rolls, cakes/muffins/puddings or ice cream by day category. 
Table 3 Proportion of children consuming selected food groups by day category and the OR for schoolday consumption

\begin{tabular}{|c|c|c|c|c|c|c|c|}
\hline \multirow[b]{2}{*}{ Food group } & \multicolumn{2}{|c|}{ Schooldays } & \multicolumn{2}{|c|}{ Non-schooldays } & \multirow[b]{2}{*}{ OR } & \multirow[b]{2}{*}{$95 \% \mathrm{Cl}$} & \multirow[b]{2}{*}{$P$ value* } \\
\hline & Proportion & $95 \% \mathrm{Cl}$ & Proportion & $95 \% \mathrm{Cl}$ & & & \\
\hline Milk & 0.66 & $0.63,0.69$ & 0.63 & $0.57,0.69$ & $1 \cdot 13$ & $0.84,1.52$ & $0 \cdot 415$ \\
\hline Meat dishes & 0.53 & $0.51,0.56$ & 0.59 & $0.53,0.65$ & 0.78 & $0.58,1.04$ & 0.086 \\
\hline Cakes/muffins/puddings & 0.28 & $0 \cdot 25,0 \cdot 30$ & 0.32 & $0.26,0.38$ & $0 \cdot 83$ & $0 \cdot 61,1 \cdot 14$ & $0 \cdot 254$ \\
\hline Hot drinks & $0 \cdot 22$ & $0 \cdot 19,0.24$ & $0 \cdot 19$ & $0.15,0.23$ & $1 \cdot 18$ & $0 \cdot 85,1 \cdot 64$ & $0 \cdot 321$ \\
\hline \multicolumn{8}{|l|}{ Hot chips ${ }^{a}$} \\
\hline NZEO & $0 \cdot 20$ & $0 \cdot 16,0.24$ & 0.33 & $0.25,0.42$ & 0.50 & $0.32,0.77$ & 0.002 \\
\hline Māori & $0 \cdot 21$ & $0.17,0.25$ & $0 \cdot 34$ & $0.26,0.43$ & 0.51 & $0.32,0.82$ & 0.005 \\
\hline Pacific & 0.25 & $0 \cdot 21,0 \cdot 30$ & 0.27 & $0 \cdot 20,0.35$ & $0 \cdot 89$ & $0 \cdot 61,1 \cdot 28$ & 0.520 \\
\hline Pies/sausage rolls & $0 \cdot 21$ & $0 \cdot 17,0.25$ & $0 \cdot 18$ & $0 \cdot 14,0.24$ & $1 \cdot 16$ & $0.75,1 \cdot 79$ & 0.495 \\
\hline Ice cream & $0 \cdot 17$ & $0 \cdot 14,0 \cdot 19$ & $0 \cdot 20$ & $0 \cdot 15,0.26$ & $0 \cdot 80$ & $0.55,1 \cdot 16$ & $0 \cdot 233$ \\
\hline \multicolumn{8}{|l|}{ Snack bars ${ }^{b}$} \\
\hline Normal weight & $0 \cdot 18$ & $0 \cdot 15,0 \cdot 21$ & 0.05 & $0.03,0.08$ & $4 \cdot 26$ & $2 \cdot 52,7 \cdot 21$ & 0.000 \\
\hline Overweight & $0 \cdot 16$ & $0.11,0.21$ & $0 \cdot 11$ & $0.05,0.23$ & $1 \cdot 48$ & $0.56,3.9$ & 0.423 \\
\hline Obese & $0 \cdot 14$ & $0.09,0.22$ & 0.01 & $0.00,0.04$ & -ब & - & - \\
\hline Yoghurt/dairy snacks & $0 \cdot 16$ & $0 \cdot 13,0 \cdot 18$ & $0 \cdot 10$ & $0.07,0.15$ & 1.63 & $0 \cdot 97,2 \cdot 71$ & 0.063 \\
\hline Bread-based dishes & $0 \cdot 14$ & $0 \cdot 12,0 \cdot 16$ & $0 \cdot 17$ & $0.14,0.22$ & $0 \cdot 76$ & $0.55,1.04$ & 0.087 \\
\hline Sausage/processed meats & $0 \cdot 13$ & $0 \cdot 11,0 \cdot 16$ & $0 \cdot 16$ & $0 \cdot 13,0.21$ & $0 \cdot 79$ & $0.54,1 \cdot 15$ & $0 \cdot 212$ \\
\hline Nuts/seeds & $0 \cdot 12$ & $0 \cdot 11,0 \cdot 14$ & $0 \cdot 12$ & $0.09,0.17$ & 0.99 & $0.65,1.50$ & 0.945 \\
\hline Fish/seafood & $0 \cdot 12$ & $0 \cdot 10,0 \cdot 14$ & $0 \cdot 12$ & $0 \cdot 08,0.17$ & 0.97 & $0.62,1.52$ & $0 \cdot 894$ \\
\hline Egg dishes & $0 \cdot 10$ & $0 \cdot 08,0.12$ & $0 \cdot 14$ & $0 \cdot 10,0 \cdot 19$ & 0.67 & $0.44,1.03$ & 0.070 \\
\hline Breadt & 0.56 & $0.53,0.59$ & 0.62 & $0.56,0.67$ & $0 \cdot 77$ & $0.58,1.02$ & 0.066 \\
\hline Sandwichest & 0.55 & $0.50,0.59$ & $0 \cdot 30$ & $0 \cdot 24,0.37$ & $2 \cdot 79$ & $2 \cdot 04,3 \cdot 82$ & 0.000 \\
\hline Breakfast cerealst & 0.48 & $0.44,0.51$ & 0.42 & $0.36,0.48$ & $1 \cdot 27$ & $0.93,1.71$ & $0 \cdot 128$ \\
\hline Grains/pastat & $0 \cdot 38$ & $0 \cdot 36,0 \cdot 41$ & 0.41 & $0.35,0.47$ & 0.91 & $0.67,1 \cdot 24$ & 0.547 \\
\hline Potato/kumara/taroł‡ & 0.33 & $0.31,0.36$ & 0.31 & $0.26,0.37$ & $1 \cdot 10$ & $0.81,1.49$ & 0.553 \\
\hline Biscuits/crackerst§ & 0.52 & $0.49,0.55$ & 0.41 & $0.34,0.48$ & $1 \cdot 60$ & $1 \cdot 15,2 \cdot 23$ & 0.005 \\
\hline Sugar/jams/syrups§ & 0.57 & $0.54,0.60$ & 0.52 & $0.46,0.57$ & $1 \cdot 25$ & $0.95,1.64$ & $0 \cdot 109$ \\
\hline Confectionery§ & $0 \cdot 31$ & $0.28,0.34$ & 0.41 & $0.34,0.48$ & 0.67 & $0.48,0.93$ & 0.016 \\
\hline Fruitł§ $\|$ & 0.68 & $0 \cdot 65,0 \cdot 70$ & 0.51 & $0.44,0.58$ & 1.99 & $1 \cdot 41,2 \cdot 80$ & 0.000 \\
\hline Powdered drinks/cordials $₫ \S$ & 0.41 & $0.38,0.44$ & 0.42 & $0.36,0.48$ & 0.95 & $0 \cdot 70,1 \cdot 28$ & $0 \cdot 729$ \\
\hline \multicolumn{8}{|l|}{ Soft drinks $\S \|^{a}$} \\
\hline NZEO & 0.28 & $0.23,0.34$ & 0.41 & $0.30,0.53$ & 0.56 & $0.34,0.94$ & 0.028 \\
\hline Māori & 0.33 & $0.28,0.38$ & 0.49 & $0.40,0.58$ & 0.51 & $0.34,0.79$ & 0.002 \\
\hline Pacific & 0.41 & $0.37,0.46$ & 0.40 & $0.31,0.49$ & 1.06 & $0 \cdot 71,1 \cdot 58$ & $0 \cdot 767$ \\
\hline \multicolumn{8}{|l|}{ Snack foods $\ddagger^{\mathrm{a}}$} \\
\hline NZEO & 0.57 & $0.51,0.62$ & 0.39 & $0.30,0.48$ & $2 \cdot 06$ & $1 \cdot 32,3 \cdot 21$ & 0.002 \\
\hline Māori & 0.60 & $0.55,0.65$ & 0.28 & $0.20,0.36$ & 3.92 & $2 \cdot 58,5 \cdot 94$ & 0.000 \\
\hline Pacific & 0.50 & $0.44,0.55$ & 0.33 & $0.23,0.44$ & $2 \cdot 04$ & $1 \cdot 22,3.42$ & 0.007 \\
\hline \multicolumn{8}{|l|}{ Vegetables $\ddagger^{\mathrm{c}}$} \\
\hline Boys & 0.38 & $0.33,0.42$ & 0.31 & $0.24,0.39$ & $1 \cdot 37$ & $0.9,2 \cdot 08$ & $0 \cdot 145$ \\
\hline Girls & 0.38 & $0.34,0.43$ & 0.45 & $0.36,0.53$ & $0 \cdot 77$ & $0.51,1.15$ & $0 \cdot 200$ \\
\hline
\end{tabular}

Significant interaction between the effect of day category and ethnicity ${ }^{\mathrm{a}}$, BMI category ${ }^{\mathrm{b}}$ and sex $^{\mathrm{c}}$ (see text).

*Logistic regression controlled for ethnicity, age, sex, New Zealand Index of Deprivation (NZDep01), BMI category, adjusted for survey weighting.

Collectively contribute $+64 \%$ daily starch, $\neq 67 \%$ daily vitamin C, $\$ 65 \%$ daily sucrose, $\| 57 \%$ daily fructose.

Tust one child in the obese category on a non-schoolday consumed a snack bar.

\section{Discussion}

To our knowledge, this is the first study to compare the intake of food and nutrients between schooldays and non-schooldays in a nationally representative sample of children. Despite differences in the proportion of consumers of some food groups between schooldays and non-schooldays, the majority of nutrient intakes (including energy) did not differ by day category.

The intake of carbohydrate was lower on non-schooldays. Sucrose intake was lower perhaps because fewer children consumed fruit and biscuits/crackers on nonschooldays, or because there was a difference in the quantity of sucrose-rich items being consumed. Sucrose intake on non-schooldays was lower despite $10 \%$ more children consuming confectionery.

Fruit was consumed by more children on schooldays, contributing to the greater fructose and vitamin $\mathrm{C}$ intake on schooldays. Other food items more commonly consumed on schooldays included sandwiches, snack foods and snack bars. An Australian survey found similar items in children's lunchboxes; typically containing 'about one sandwich, two biscuits, a piece of fruit, a snack of either a muesli/fruit bar or some other packaged snack ${ }^{,(14)}$. The most significant contributors to NZ children's energy intakes on schooldays (09.00-12.00 hours) were snack foods (22\%) and biscuits (20\%); at lunchtime, sandwiches (33\%) and fruit $(12 \%)^{(5)}$. These data support $84 \%$ 
of children's statements that they bring 'most' of their food consumed at school from home ${ }^{(9)}$, as in Australia ${ }^{(16)}$.

Consumption of 'unhealthy' foods is ubiquitous. For Australian children, fast foods, including hot chips and pies/sausage rolls, contributed $\sim 10 \%$ energy at school and $11 \cdot 8 \%$ out of school ${ }^{(15)}$. In NZ, the 'villains' of the tuck shop are considered to include pies/sausage rolls, hot chips and soft drinks/sweetened beverages. However, these are just as likely to be consumed on a nonschoolday. Hot chips are twice as likely to be consumed on a non-schoolday, and intake during school hours is negligible ${ }^{(16)}$. Soft drinks and other sweetened beverages are considered to contribute to obesity ${ }^{(17)}$, but as the intake of powdered drinks/cordials did not vary by day category, and soft drink consumption was higher on non-schooldays for Māori/NZEO, the issues could not be adequately addressed by focusing solely on foods available on the school premises. This is in spite of the strenuous efforts by health professionals to encourage schoolchildren to choose water or milk to drink. It appears that, in agreement with previous research, children obtain or choose the foods that they prefer and foods that are readily available at home, and foods that they and their families and/or peers find convenient and affordable ${ }^{(18)}$. The data presented indicate that a hungry child in search of hot food in NZ, whether on a schoolday or non-schoolday, can more readily access hot chips or a pie than soup or a rice-based dish. In order to influence the food choices and nutrition of NZ schoolchildren, affordable and accessible food alternatives need to be available at home, in shopping malls and convenience stores and in school tuck shops. Pasta and rice-based dishes need to be stored in home refrigerators, sold in the context of fast-food outlets and as part of the offerings in the school environment. This has the potential to increase intakes of calcium and vitamin A among schoolchildren without increasing energy or fat intake.

The present study has some limitations: the classification of food groups means that the prevalence of consumption of some foods may be under-reported. For example, vegetable/meat/cheese fillings in sandwiches will not be counted. It is difficult to compare consumption within 'school hours' between day categories because patterns of consumption throughout the day are likely to vary, particularly in the oldest age group. For example, many teenagers may rise later on non-schooldays. While distribution of children's characteristics (sex, ethnicity) varies by day category, this is accounted for in the regression.

Altering the school environment is one avenue to effect a positive change in children's diets. However, as only approximately one-third of a child's daily energy intake is consumed during school hours ${ }^{(5,15)}$ this is only a partial solution. The public health focus has been on the foods consumed by children at school, with emphasis on the regulation of foods sold at school tuck shops/canteens.
Schools can influence on-site provision and policies can affect food choice such as prohibiting leaving school grounds during school hours. Schools may provide guidance on what may or may not be brought to school. However, the present study reinforces the fact that the family environment and what is provided from home is the mainstay of nutrition for $\mathrm{NZ}$ children. Where improvement is needed to children's diets, attention must be made to the foods provided by parents, regardless of where they are consumed. Parents who are time constrained need to be able to provide for their children, directly or indirectly, a wider range of hot food items.

\section{Acknowledgements}

The Ministry of Health funded the 2002 Children's Nutrition Survey (CNS). Other principal investigators for the survey came from the University of Auckland (David Schaaf, Robert Scragg) and Massey University (Eljon Fitzgerald). The authors declare that they have no competing interests. W.R.P. and N.C.W. were both principal investigators on the 2002 Children's Nutrition Survey. N.C.W. and W.R.P. conceived the initial idea for the analysis. J.E.R. and P.M.L.S. managed the data. J.E.R. performed the statistical analyses and drafted the initial and final manuscripts. J.E.R. and A.R. performed relevant literature searches. W.R.P., N.C.W., P.M.L.S. and A.R. provided a detailed critical review. The authors thank Andrew Gray, Department of Social and Preventive Medicine, University of Otago, for his advice on statistical methodology. The authors also thank all participants in the CNS 2002.

\section{References}

1. Carter MA \& Swinburn B (1999) Measuring the impact of a school food programme on food sales in New Zealand. Health Prom Int 14, 307-316.

2. Bere E, Veierod MB, Bjelland M et al. (2006) Outcome and process evaluation of a Norwegian school-randomized fruit and vegetable intervention: Fruits and Vegetables Make the Marks (FVMM). Health Educ Res 21, 258-267.

3. Bell AC \& Swinburn BA (2005) School canteens: using ripples to create a wave of healthy eating. Med J Aust 183, 5-6.

4. Ministry of Education (2001) School dates 2002. http:// www.minedu.govt.nz/theMinistry/EducationInNewZealand/ SchoolTermsAndHolidays/SchoolTermsArchive.aspx/

5. Regan A, Parnell W, Gray A et al. (2008) New Zealand children's dietary intakes during school hours. Nutr Diet 65, 205-210.

6. Cullen KW, Lara KM \& de Moor C (2002) Children's dietary fat intake and fat practices vary by meal and day. J Am Diet Assoc 102, 1773-1778.

7. Haines PS, Hama MY, Guilkey DK et al. (2003) Weekend eating in the United States is linked with greater energy, fat, and alcohol intake. Obes Res 11, 945-949.

8. Cameron JE, Macdiarmid JI, Craig LCA et al. (2008) Frequency of meal and snack consumption and nutrient intake in schoolchildren in Scotland: term-time $v$. holidays and weekdays $v$. weekends. Proc Nutr Soc 67, OCE6, E219. 
9. Parnell W, Scragg R, Wilson N et al. (2003) NZ Food, NZ Children: Key Results of the 2002 National Children's Nutrition Survey. Wellington: Ministry of Health; available at http://www.moh.govt.nz

10. Ministry of Health (2007) Food and Beverage Classification System. Wellington: Ministry of Health.

11. Salmond C \& Crampton R (2002) NZDep2001 Index of Deprivation. Wellington: Department of Public Health, University of Otago.

12. Crop and Food Research (1993) Food Files. The New Zealand Food Composition Database. Palmerston North: NZ Institute of Crop and Food Research.

13. Cole TJ, Bellizzi MC, Flegal KM et al. (2000) Establishing a standard definition for child overweight and obesity worldwide: international survey. BMJ 320, 1240-1243.
14. Sanigorski AM, Bell AC, Kremer PJ et al. (2005) Lunchbox contents of Australian school children: room for improvement. Eur I Clin Nutr 59, 1310-1316.

15. Bell AC \& Swinburn BA (2004) What are the key food groups to target for preventing obesity and improving nutrition in schools? Eur J Clin Nutr 58, 258-263.

16. Regan A (2007) New Zealand children's dietary intakes during school hours; results from the National Children's Nutrition Survey 2002. MSc Thesis, University of Otago.

17. Taylor R, Scragg R \& Quigley R (2005) Do Sugary Drinks Contribute to Obesity in Children? Agencies for Nutrition Action. Wellington: Scientific Committee of Agencies for Nutrition Action.

18. Larson N \& Story M (2009) A review of environmental influences on food choices. Ann Behav Med 38, S56-S73.

\section{Appendix}

\section{Food group definitions*}

\begin{tabular}{ll}
\hline Food group & Examples \\
\hline Milk & Cow, soya, flavoured, shakes, powder \\
Snack foods & Potato crisps, corn chips, vegetable/grain crisps, popcorn, extruded snacks \\
Meat dishes & Poultry, beef, lamb, pork, offal \\
Cakes/muffins/puddings & Also slices, scones, pancakes, pastries, milk puddings, desserts \\
Hot drinks & Chocolate, cereal beverages; excludes tea/coffee \\
Hot chips & Fries, wedges, croquettes/hash browns \\
Pies/sausage rolls & Meat pies, bacon egg pie, quiche \\
Ice cream & Regular, novelty, reduced-fat \\
Snack bars & Muesli, puffed cereal, nut/seed, breakfast cereal-based \\
Yoghurt/dairy snacks & Regular, reduced-fat, frozen, dairy 'food' \\
Bread-based dishes & Hotdogs, hamburgers, pizza, nachos \\
Sausage/processed meats & Luncheon, saveloys, meat-loaf/patties; excludes sausage rolls \\
Nuts/seeds & Peanut butter, Nutella'M, coconut milk/cream \\
Fish/seafood & Canned, battered/crumbed, shellfish, fish/seafood dishes, products \\
Egg dishes & Omelettes, self-crusting quiches \\
Bread & All types: rolls, pita, bagels, crumpets, sweet buns \\
Sandwiches & Filled rolls, pita, croissants \\
Breakfast cereals & Muesli, wheat biscuits, porridge, puffed/flakes/extruded cereals \\
Grains/pasta & Rice, pasta, cereal-based dishes (lasagne) \\
Potato/kumara/taro & Mashed, boiled, baked, scalloped, stuffed (excludes crisps/fried potato) \\
Biscuits/crackers & Plain, coated, filled \\
Sugar/jams/syrups & Honey, jelly, sweet toppings, icing \\
Confectionery & Lollies/candy, gum, chocolate, ice-blocks \\
Fruit & Fresh, cooked, canned, dried \\
Powdered drinks/cordials & Fruit-flavoured \\
Soft drinks & Carbonated, sports/energy drinks \\
Vegetables & All vegetables (except potato/kumara/taro), legumes/pulses, dishes \\
&
\end{tabular}

${ }^{*}$ Full list in Parnell et al. ${ }^{(9)}$ 